\title{
Elazığ ve Malatya'da Bazi İlköğretim Binalarının Isıl Konfor ve Koruma Değerlendirmesi
}

\author{
Sevil AY' ${ }^{1}$, Nurdan BAYKUŞ ${ }^{2}$, Cevdet Emin EKİNCí ${ }^{3}$ \\ ${ }^{1}$ Artvin Çoruh Üniversitesi, Borçka Acarlar MYO, İnşaat Bölümü Artvin, Türkiye \\ ${ }^{2}$ Kilis 7 Aralık Üniversitesi, MYO, İnşaat Bölümü Kilis, Türkiye \\ ${ }^{3}$ Fırat Üniversitesi, Teknoloji Fakültesi, İnşaat Mühendisliği, Elazığ, Türkiye
}

\begin{abstract}
ÖZET: Ĕ̆itim yapıları; toplumsal yapının temelini oluşturan, ülkenin geleceğine yön veren, başarılı ve sağlıklı toplumları oluşturan bireylerin yetiştirilmesini sağlayan, özel olarak planlanması gereken en önemli mekanlardandır. Çalışmada Elazığ ve Malatya'daki okullar arasından belirlenen ve deneysel olarak incelenen binalarda, Aralık ayında sıcaklık ve bağılnem değerleri ölçülmüştür. İlköğretim binalarının ısıl konfor şartları BUD ve IPI Koruma değerlendirmeleri temel alınarak incelenmiştir. Okulların 1sıl konfor şartları; kullanıcı sağlığı, eğitimin kalitesi ve verimliliği açısından oldukça önemlidir. Deneysel çalışmanın sonunda, incelenen okulların BUD ve IPI değerlendirmeleri esaslarına göre belli başlı eksikliklerinin olduğu anlaşılmıştır. Ayrıca, öğrencilerin zamanlarının çoğunu geçirdikleri dersliklerin çok daha olumsuz koşullara sahip olduğu tespit edilmiştir.
\end{abstract}

Anahtar Kelimeler:Biyoharmoloji, Sıcaklık, Bă̆ıl Nem, Çiğ Noktası Sıcaklı̆̆ı, Koruma Değerlendirmesi, İlköğretim Okulu

\section{Thermal Comfort and Protection Raiting in Primary Schools at Elazig and Malatya}

\begin{abstract}
One of the most important places is educational building which forms basis of social structure, shapes the future of states, provides to train people who belong to healthy and successful society, and should be planned with special methods. In this research, temperature and relative humidity rate were measured among scientifically examined schools in Elazı ğ and Malatya at December. Primary educational buildings' thermal comfort conditions were investigated base on BCA and IPI protection raiting. Thermal comfort conditions in schools are quite important in terms of health of users, quality and productivity of education. As a result of research, these buildings have some major deficiencies with regards to evaluation of BCA and IPI protection. Furthermore, classrooms in the examined buildings which are used to spend time by students, have poorer conditions.
\end{abstract}

Keywords: Bioharmology, Temperature, Relative Humidity, Dew Point Teperature, Protection Raiting, Elementary School

\section{GIRISŞ}

Yapı ile çevre karşılıklı olarak bir etkileşim içindedir. Çevre; yapılar üzerinde bir takım olumsuz etkilerde bulunurken, yapılar; yerel çevre, iç çevre ve küresel çevre üzerinde bir etkide bulunmaktadır. Bu etkileşimin sonucunda, kişi sağlığının doğrudan veya dolaylı olarak bozulma riski oluşmakta ve çalışma verimliliği düşmektedir. Bu doğrultuda kişilerin sağlıklı olabilmelerini etkileyen en önemli faktör, çevresel faktörler dolayısıyla da fiziki çevre olarak karşımıza çıkmaktadır. $\mathrm{Bu}$ nedenle fiziki çevre; toplumda aktivitelerin, ilişkilerin, öğrenmenin gerçekleştiği, iç ve dış öğrenme mekanlarınınbulunduğualanlardır. Bu alanlar, bir kişinin evde çalışması için düzenlenmiş bir odadan, binlerce kişi ve öğrenciler için tasarlanan bir üniversite kampüsüne kadar uzanmaktadır. Dolayısıyla fiziki çevrenin de, öğrenme çevresi ve sosyal çevre gibi, etkili bir eğitim çevresi oluşturmakta önemli bir etken olduğu görülmektedir [2, 7 ve 10].
Eğitim ortamlarının temeli olan sınıflar; öğretmen ve öğrencilerin eğitim hedeflerine ulaşabilmek amacıyla zaten var olan ve çeşitli iletişim araçlarıyla edindikleri bilgi ve yaşantıları, elverişli bir düzenleme ile paylaştıkları yerdir. Bundan dolayı, eğitim yapılarının fiziksel ortam bakımından uygunluğu, hem öğrenmeöğretme sürecindeki etkililiği hem de öğrenci tutum ve davranışlarının geliştirilmesi açısından önemli bir etkiye sahiptir. Eğitim ve öğretimin gerçekleştiği ortamların yani sınıfların yönetimi, çoğunlukla sınıfta disiplini sağlamak olarak düşünülmektedir. Fakat günümüzde sınıf yönetimi, eğitim öğretim etkinlikleri başta olmak üzere sınıfta olumlu iklimin oluşturulmasını içerir. Sınıfta yer alan her değişkenler, eğitime destek ya da engel olabilmektedir. Sınıf yönetiminin belli başlı amacı olumlu ve beklenilen öğrenme çevresini oluşturarak, öğrencilerin öğretim amaçlarına ulaşmalarını sağlamaktır. Sadece mekanda yer alan eşyalar/materyaller değil, bunların görünümleri ve düzenlenişleri de eğitsel açıdan kişiler üzerinde çok önemli ve etkileyici olmaktadır. Sınıf yönetiminde sınıf düzeni, sınıfın hedefine ulaşabilmesi için gereksinim 
duyduğu araçlarla kuşatılması ve bu araçların ekonomik şekilde çalışacakları ya da en verimli olacakları bölümlere yerleştirilmesi anlamını taşımaktadır. Sınıftaki öğrencilerin sayısı, 1Sı, 1şık, gürültü düzeyleri, duvar ve eşya renkleri, temizlik ve görünümöğrencilerin algılama biçimlerine önemli etlileri vardır. Mekan şekilleri, eşyaların/mobilyaların tasarımı gibi faktörler, hem öğretmenler hem de öğrenciler tarafindan gönderilen gizli mesajları kapsayan fiziksel ipuçlarıdır. Böylesine gizli mesajlar, öğrenciyi harekete geçirir, katılımı teşvik eder, dikkati bir şeye toplar ve öğrencilerin istendik davranış sergilemelerini sağlar. Sınıfların tasarlanması sadece teknik bir durum değildir, ayrıca öğretmenin tarzını da yansıtmaktadır. Dolayısıyla okullardaki öğrenme ortamlarına şekil verirken fiziki çevrenin kontrolü ve öğretmenin bu konudaki farkındalığı bir takım fiziki rahatsılıkları engellemede oldukça önemlidir. Burada kullanılacak araç-gereç ve bu araç-gereçleri kullanacak kişilerin (öğretmen-öğrenci) birbirleriyle uyumlu ve birbirini tamamlayıcı olmasına dikkat edilmelidir. Bu doğrultuda fiziki mekan yönetimi öğrencilerin, yöneticilerin ve çalışanların hem rahat hem de güzel bir atmosferde eğitim-öğretim etkinliklerini sürdürmelerini sağlayacak en yararlı fiziksel çevreyi oluşturmakla gerçekleşmektedir [1, 6, 8, 10 ve 15].

Fiziksel ortam ise eğitim faaliyetleri için ayrılan mekânın niteliklerini belirtmektedir. Okulların ve de sınıfların fiziksel ortam değişkenleri arasında sınıftaki öğrenci sayısı, 1sı derecesi, aydınlık düzeyi, gürültü düzeyi, duvarların/eşyaların renkleri, temizliği ve görünümü gibi ölçütler sayılabilir. Okulun ve sınıfın fiziksel düzeni/uyumu, öğrencilerin hem sosyal hem de iletişim davranışlarını önemli ölçüde etkileyebilmektedir. Sınıfın fiziksel yapısının iç karartıcı, düzensiz, havasız, çok soğuk ya da çok sıcak, gürültülü ve de sınıf dışı olumsuzluklara açık olması öğrenciyi dolayısıyla da eğitimin verimliliğini olumsuz yönde etkileyecektir. Eğitimde istenen davranışlar nedeniyle başarının sağlanmasında eğitim programları ve öğretmen yetiştirme yöntemlerinin yanında farklı disiplinlerde ileri sürülen (başta halk sağlığı olmak üzere sosyoloji, psikoloji, fizyoloji, çevre mühendisliği, mimarlık, peyzaj mimarlığı, iç mimarlık, ergonomi, endüstri mühendisliği vs. gibi disiplinler) konuların eğitim ve öğretime iletilmesi ve ilişkilendirilmesinin faydalı olacağı düşünülmektedir. Bu disiplinlerden biri de biyoharmoloji bilimidir [15].

Biyoharmoloji kısaca "uyum ve denge bilimi"dir. Yapı ve canlı arasında bir etkileşimin söz konusu olduğunu; renk, doku, şekil, oran, ölçek, denge, ritim, vurgu, biçim gibi daha pek çok mekânsal nitelerin kullanıcısını etkilediği ve bu nedenle yapıların-binaların kullanıcı kimliği ve kullanım amacına göre tasarlanması ve uygulanması gerekliliğini savunmaktadır. Bu nedenle, yapıların kullanıcıların kimlik ve ihtiyaçlarını karşılamaya yönelik olması gerektiğini savunur. Bundan dolayıbiyoharmoloji geniş bir süreçtir. $\mathrm{Bu}$ süreçte canlıların esas ihtiyaçları olan beslenme, uyuma, dinlenme ve çalışma ortamlarının ne derecede uygun olup olmadığınısorgular. Her yapının konfor koşullarını (görsel, işitsel ve isısal konfor şartlarını) sağlamak amacıyla, işlevinden, tasarımından ve konumundan kaynaklanan kendine has gereksinimleri söz konusudur. Bir binadan kullanıcıların hoşnutluğu, kişileri karşılıklı olarak etkileyen birçok faktöre bağlıdır. Faktörlerin çokluğu sonuçların bir bütün gibi değerlendirmesini zorlaştırır. İnsanların psikolojik, biyolojik ve sosyokültürel ihtiyaçlarını karşılayabilmek amacıyla yarattıkları yapay çevrenin, böylesi ihtiyaçlara cevap verebilecek konfor koşullarına ve iç hava kalitesine (huzur kriterlerine) sahip olması gerekmektedir. Diğer durumlardamekan kullanıcılarının performansları ve iş verimleri düşeceği gibi, orayı kullanan kişilerin sağlıkları da bozulacaktır [2, 9, 13 ve 14].

Diğer taraftan, gelişen teknoloji ile beraberkişilerin kapalı ortamlarda bulundukları süreler gün geçtikçe artmakta ve bu yüzden ortam huzuru daha da önemli olmaktadır. Okullar, iş yerleri, hastaneler, sinemalar, restoranlar gibi çok sayıda kişinin bulunduğu kapalı ortamların huzur kriterlerinde tutulabilmesiyle kişilerin daha mutlu ve de daha verimli olabilmeleri sağlanmaktadır. Bu konuda yapılan araştırmalara göre huzur kriterlerine sahip ortamlarda bulunan kişiler, bu kriterlere sahip olmayan ortamlarda bulunan kişilere göre daha verimli ve daha mutlu olabilmektedir [4].

Okullar; tüm bir ulus için yaşamın merkezi konumundadır. Okullar, öğrenci ve personelin verimlilik, refah ve sağlığını olumsuz olarak etkileyen çevresel sorunlar oluşturmaktadır. $\mathrm{Bu}$ nedenle okulların ve kullanıcılarının sağlığını, eğitimin kalitesini ve de verimliliğini olumsuz bir şekilde etkileyen fiziksel çevre unsurlarını oluşturan huzur kriterleri oldukça önemli bir yere sahiptir. Bu huzur kriterlerinden biri olan 1sil konfor şartları; sıcaklık, bağıl nem ve çiğ noktası sıcaklığı parametrelerinden oluşmaktadır. Isıl konfor ise bir ortamdaki ssıl memnuniyeti ifade eder. Son elli yıldan fazla bir süredir, kapalı ortamda hava kirliliğine maruz kalmak bazı faktörlerden dolayı artmıştır. Bu faktörlerin arasında bina inşaatlarının çok sık olması, sentetik yapı malzemelerinin ve mobilyalarının kullanımı, enerji tasarrufundan dolayı havalandırma sürelerinin azalması, böcek zehirleyicileri, bakım malzemeleri kullanımı sayılabilir. Bunlara ek olarak, para harcamamak amacıyla bakım ve onarım işlerini ertelemeye çalışmak gibi yapılan girişimler bazı problemlere sebep olabilmektedir. Kapalı ortamlardaki hava problemleri sinsi olabilir. Bu durum da sağlık, ruh ya da fiziksel çevre üzerinde kolayca fark edilemeyeceketkiler oluşturmaktadır. Yetersiz hava şartlarına maruz kalmak, öğrencilerin öğrenmelerini, verimliliğini ve başarılarını olumsuz yönde etkilemektedir. Kamu okullarındaki hava kalitesi, öğrencilerin dikkat kabiliyetlerini önemli derecede etkilemektedir. Gençlerin özellikle de on yaşın altında olan çocukların yetişkinlere göre okullarda 
bulunan kirletici türlerine (asbest, radon, formaldehit) karşı daha da hassas oldukları ortaya çıkmıştır. Mekan kullanıcılarının sağlığını tehlikeye atabilecek derecede radyasyon, gaz-duman ve mikroorganizma türlerinden

\section{2. ÇALIŞMANIN ÖNEMI}

Biyoharmolojik Uygunluk Değerlendirmesi (BUD) beş temel aşamadan oluşmaktadır. Bunlardan birincisi Ön Teknik İnceleme (ÖTİ); ikincisi 14 kriterli "Planlama, Projelendirme ve Uygulama (PPU)"; üçüncüsü 18 kriterli "Mekansal Niteliklerin Yansıma Düzeyi (MNYD)"; dördüncüsü "Yaşam Alanı Biyoharmolojik Uygunluk Değerlendirmesi (YABUD)" ve beşincisi de Kullanıcı Memnuniyeti (KM)'dir. Son iki aşama olan YABUD ve KM, ilk üç aşama bulguları 1şı̆̆ında ve ihtiyaç durumunda yapı fiziği ve biyolojisi şartları kapsamındaki yaşam kalitesini ve canlı sağlığını olumsuz yönde etkileyen ortam parametrelerinin incelendiği; kullanıcı hoşnutluğu ve memnuniyet

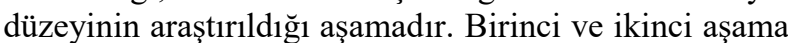
yapının mühendislik, üçüncü aşama mimarlık, dördüncü aşama yaşam alanlarının özellikle yapı fiziği ve biyolojisi ve beşinci aşama ise kullanıcıların memnuniyet düzeyi incelenmektedir.

IPI ise Image Permanence Institute'nin kısaltmasıdır. IPI kar amacı gütmeyen bir kurum olup yükseköğretim tabanlı laboratuar araştırmaları yapan bir kurumdur. Sahip olduğu laoratuar dünyanın en büyük ve en kapsamlı laboratuarı olarak bilinir. The Andrew W. Mellon Foundation çatısı altında Rochester Institute of Technology ve Society for Imaging Science and Technology sponsorluğunda 1985 yılında Newyork'ta kurulmuştur.

Eğitsel, fiziksel ve ruhsal performanslarını etkileyecek okullardaki olumsuz çevre şartları, öğrenci, öğretmen ve okul yöneticilerin anlık, dönemlik ve/veya hayat boyu sürebilecek olumsuz sonuçlar olușturabilir. $\mathrm{Bu}$ nedenle, bu çalışmada; ilköğretim okullarının ısıl konfor ve koruma değerlendirmesi deneysel olarak incelenmiştir. Örneklem olarak Elazı̆̆ ve Malatya'da bazı ilköğretim binalarıdır.

Eğitim kurumlarında mekanlar iki ana neden yüzündenkamuda özel ilgi alanı olarak görülmektedir. $\mathrm{Bu}$ nedenlerden biri; okulların, diğer binalara göre fiziksel eksikliklerin daha fazla olduğu bir yer olarak karşımıza çıkmasıdır. Çünkü maliyetler hakkındaki yetersizlikler, eğitim kurumlarının çok daha iyi bir şekilde işletilmesini zorlaştırmaktadır. Diğer nedense; çocukların yetişkinlere göre çevre kirliliklerine karşı çok daha duyarlı olmalarıdır. Bunun yanı sıra çocukların, ev dışında daha fazla vakit geçirdikleri yerler okullardır [5 ve 10$]$.

Kapalı ortamlar, kişilerin zamanlarının \%8090’’nı geçirdiği konutlar, okullar, resmi binalar, eğlence uzak olan bir okul, hava kalitesine yani huzur kriterlerine sahip demektir. Çeşitli boyalar, yapıştırıcılar, kozmetik ürünler, 1s1 ve elektrikli aletler ve küf rahatsız edici bir etkiye neden olabilmektedir [3, 10, 11, 12 ve 15].

yerleri ve taşıtlar gibi mekanlardır. Kapalı ortamlarda 1s1, 1şık, gürültü düzeyleri gibi etkenler ile birlikte ortam havasının da orada yaşayan kişilerin verimlilikleri, sağlıkları ve rahatları üzerine etkileri vardır. Fakat bu etkinin yeterince dikkate alınmamasının nedeni, kapalı ortam hava kirliliği faktörlerinin genelde uzun sürede oluşması ve yaşam ile birlikte sağlığı doğrudan veya acil olarak tehdit etmemesidir [2].Kapalı ortamlardaki konfor şartları (huzur kriterleri) mekanın görsel, işitsel ve ısıl konfor şartlarına bağlıdır. Mekanların konfor koşulları belirlenirken kullanıcılarıncinsiyeti, yaşı, kullanıcı sayısı ve ortamların/mekanların kullanım amaçlarına uygun bir şekilde tespit edilmesi gerekmektedir [4].

Çalışmada, eğitim yapılarının bazı bölümlerinde 1sıl konfor şartlarını belirleyen unsurların değerleri tespit edilerek bu değerlerin kullanıcılar ve fiziki ortam elemanları üzerine olan etkileri biyoharmoloji açısından incelenmiştir. $\mathrm{Bu}$ etkiler; Biyoharmolojik Uygunluk Değerlendirmesi (BUD) ve Image PermanenceInstitute (IPI) esasları baz alınarak değerlendirilmiştir. IPI koruma değerlendirmesi hesaplamaları fiziki ortamı oluşturan elemanlardan biri olan malzemeler/yapı malzemeleri üzerinde bazı hasarlara neden olmaktadır (Tablo 3). Bu hasarlar nedeni ile oluşan çürümeler çevrenin korunma kalitesini dolayısıyla da kullanıcıların sağlığını olumsuz bir şekilde etkilemektedir. Deneysel çalışma eğitim yapılarının ısıl konfor şartları ve koruma değerlendirmeleri açısından ele alınan ilk çalışmalardan biri olması nedeni ile bundan sonra yapılabilecek olan çalışmalara bir örnek teşkil etmektedir. $\mathrm{Bu}$ çalışma ile elde edilen veriler eğitim yapılarının tasarımı, yönetimi ve fiziki ortamın 1sıl konfor şartlarının hangi değerlerde tutulmasının sağlanması hususunda benzer çalışmalara örnek olabilecek önemli sonuçlar sunmaktadır.

\section{YÖNTEM}

Deneysel çalışma Elazığ ve Malatya illerinde İl Milli Eğitim Müdürlüklerinin yazılı onaylarında belirtmiş oldukları okullarda Aralık ayında ölçülen değerlerin kullanılması ile oluşturulmuştur. Araştırma kapsamında bulunan okulların sıcaklık ve bağıl nem değerlerinin tespiti için DT-8820 Environment Meter cihazı kullanılmıştır. Sıcaklık, bağıl nem ve çiğ noktası sıcaklığı arasındaki ilişkiyi sunmak için çiğ noktası sıcaklığı ve IPI koruma değerlendirmeleri Image PermanenceInstitute'nin resmi sitesi olan http://www.dpcalc.org üzerindeki hazır paket programı kullanılarak hesaplanarak tablolaştırılmıştır. Tablo 1 ve 2'de çiğ noktası sicaklığı ve ortamın sicaklık değerlerinin Biyoharmoloji bilimi açısından kişiler üzerine olan etkileri verilmiştir. Tablo 3 'te ise çiğ noktası sıcaklığının 
malzeme üzerinde oluşturabileceği çürüme hasarları ve koruma indeksleri verilmiştir.

IPI koruma değerlendirmesine esas olan 4 farklı çürüme/hasar türü çevre kaynaklı risk derecelerini belirtmektedir. Bu dereceler; Doğal yaşlanma (kimyasal çürüme: Organik maddelerin (kağıt, ahşap, plastik, boya vs.) spontan/kendiliğinden değişim oranı ile tespit edilen malzemelerdeki kimyasal bozunma oranını ifade etmektedir), Mekanik Hasar (Fiziksel çürüme: Çevre kaynaklı fiziksel veya yapısal malzeme bozulmasını ifade etmektedir), Küf Riski (Kalıp riski: Malzemelerdeki kalıp çimlenme riskini (biyolojik çürüme) ve küf büyüme potansiyelini ifade etmektedir) ve Metal korozyonudur (Metal malzemelerin çevre kaynaklı korozyon riskini ifade etmektedir) [17].

Tablo 1. Ciğ Noktası Sicaklığı Bakımından Biyoharmolojik Uygunluk Değerlendirmesi (BUD) [16]

\begin{tabular}{|l|l|}
\hline $\begin{array}{c}\text { Çiğ Noktası } \\
\text { Sıcaklığı } \\
\left({ }^{\circ} \mathbf{C}\right)\end{array}$ & \multicolumn{1}{c|}{$\begin{array}{c}\text { Çiğ Noktası Sıcaklığı Bakımından Kişiler } \\
\text { Üzerindeki Etkiler }\end{array}$} \\
\hline$\geq 24$ & Son derece rahatsız edici, Bunaltıcı hava \\
\hline $21-23$ & Çok nemli, Bunaltıcı hava \\
\hline $18-20$ & Çoğu kişi için bunaltıcı hava \\
\hline $15-17$ & $\begin{array}{l}\text { Çoğu kişi için iyi ancak bazıları için bunaltıcı, } \\
\text { Nemli hava }\end{array}$ \\
\hline $12-14$ & Rahat hava \\
\hline $9-11$ & Çok rahat hava \\
\hline $8 \leq$ & Kuru hava \\
\hline
\end{tabular}

Tablo 2. Sicaklık Bakımından Biyoharmolojik Uygunluk Değerlendirmesi (BUD) [16]

\begin{tabular}{|l|l|}
\hline $\begin{array}{c}\text { Sıcaklık } \\
{ }^{\mathbf{}} \mathbf{C}\end{array}$ & $\begin{array}{c}\text { Sıcaklığın Fiziksel Etkisi Bakımından } \\
\text { Kişiler Üzerindeki Etkiler }\end{array}$ \\
\hline$>28$ & Yüksek derecede rahatsız edici \\
\hline $27-28$ & Rahatsızlık hissi başlar \\
\hline $25-26,9$ & Geçiş değeri (Sıcak) \\
\hline $17-24,9$ & Rahat ortam hissi \\
\hline $15-16,9$ & Geçici değer (soğuk) \\
\hline $15<$ & Rahatsızlık hissi başlar \\
\hline
\end{tabular}

Tablo 3. IPI Koruma Değerlendirmesi [17]

\begin{tabular}{|c|c|c|c|c|}
\hline $\begin{array}{l}\text { Çürüme / } \\
\text { Hasar }\end{array}$ & \multicolumn{3}{|c|}{ Koruma İndeksleri } & $\begin{array}{r}\text { Koruma } \\
\text { Metriği }\end{array}$ \\
\hline \multirow{2}{*}{$\begin{array}{l}\text { Doğal } \\
\text { Yaşlanma }\end{array}$} & $\geq 75$ & $75-45$ & $\leq 45$ & \multirow{8}{*}{$\begin{array}{l}\text { DNI: Denge } \\
\text { Nem Íçeriği } \\
\text { (\%) } \\
\text { KG: Küf } \\
\text { Günü } \\
\text { Kí: Koruma } \\
\text { Indeksi }\end{array}$} \\
\hline & İyi & OK & Risk & \\
\hline \multirow{2}{*}{$\begin{array}{l}\text { Mekanik } \\
\text { Hasar }\end{array}$} & \multicolumn{2}{|c|}{$\geq 5-12,5 \leq$} & OK & \\
\hline & \multicolumn{2}{|c|}{$\leq 4,9-12,6 \geq$} & Risk & \\
\hline \multirow[b]{2}{*}{ Küf Riski } & $\geq 0,5$ & Risk & Oluşur & \\
\hline & $\leq 0,5$ & Risk Yok & Oluşmaz & \\
\hline \multirow{2}{*}{$\begin{array}{l}\text { Metal } \\
\text { Korozyon }\end{array}$} & $\leq 7$ & $7,1-10,5$ & $\geq 10,6$ & \\
\hline & İyi & OK & Risk & \\
\hline
\end{tabular}

\section{BULGULAR}

Elazığ ve Malatya illerinde yazılı izinler sonucu belirlenmiş olan her ilde bir devlet okulu bir de özel okul olmak üzere toplam 4 ilköğretim okulunda güz döneminde yapılmış olan sıcaklık ve nem düzeylerine ait ölçüm sonuçları ve bu sonuçlara ait BUD ve IPI koruma değerlendirmeleri Tablo 4, 5, 6, 7 ve 8'de belirtilmiştir.

\begin{tabular}{|c|c|c|c|c|c|c|}
\hline \multirow[b]{2}{*}{ OKULLAR } & \multicolumn{4}{|c|}{$\begin{array}{c}\text { MEKANIN MEVCUT ISIL KONFOR } \\
\text { ŞARTLARI }\end{array}$} & \multicolumn{2}{|c|}{ BUD DEĞERLENDİRMESİ } \\
\hline & İncelenen Ortam & $\begin{array}{l}\text { Sicaklik } \\
\quad\left({ }^{\circ} \mathrm{C}\right)\end{array}$ & $\begin{array}{c}\text { Nem } \\
(\%)\end{array}$ & $\begin{array}{c}\text { Çiğ } \\
\text { Noktası } \\
\text { Sicaklığ1 } \\
\left({ }^{\circ} \mathrm{C}\right)\end{array}$ & $\begin{array}{l}\text { Çiğ Noktası } \\
\text { Sicaklığı } \\
\text { Bakımından }\end{array}$ & $\begin{array}{l}\text { Sicaklığın Fiziksel } \\
\text { Etkisi Bakımından }\end{array}$ \\
\hline \multirow{6}{*}{ OKUL 1} & Giriş/ Danışma & 20 & 40 & 6 & Kuru Hava & Rahat Ortam Hissi \\
\hline & Derslik-1 & 19 & 65 & 12 & Rahat Hava & Rahat Ortam Hissi \\
\hline & Derslik-2 & 18 & 65 & 12 & Rahat Hava & Rahat Ortam Hissi \\
\hline & Derslik-3 & 19 & 70 & 13 & Rahat Hava & Rahat Ortam Hissi \\
\hline & Lab.-1 & 20 & 50 & 9 & Çok Rahat Hava & Rahat Ortam Hissi \\
\hline & Ana Koridor & 20 & 47 & 8 & Kuru Hava & Rahat Ortam Hissi \\
\hline \multirow{6}{*}{ OKUL 2} & Giriş/ Danışma & 21 & 38 & 6 & Kuru Hava & Rahat Ortam Hissi \\
\hline & Derslik-1 & 21 & 64 & 14 & Rahat Hava & Rahat Ortam Hissi \\
\hline & Derslik-2 & 22 & 49 & 11 & Çok Rahat Hava & Rahat Ortam Hissi \\
\hline & Derslik-3 & 23 & 41 & 9 & Çok Rahat Hava & Rahat Ortam Hissi \\
\hline & Lab.-1 & 23 & 38 & 7 & Kuru Hava & Rahat Ortam Hissi \\
\hline & Ana Koridor & 21 & 41 & 8 & Kuru Hava & Rahat Ortam Hissi \\
\hline \multirow{6}{*}{ OKUL 3} & Giriş/ Danışma & 22 & 35 & 6 & Kuru Hava & Rahat Ortam Hissi \\
\hline & Derslik-1 & 20 & 49 & 9 & Çok Rahat Hava & Rahat Ortam Hissi \\
\hline & Derslik-2 & 21 & 51 & 11 & Çok Rahat Hava & Rahat Ortam Hissi \\
\hline & Derslik-3 & 23 & 49 & 12 & Rahat Hava & Rahat Ortam Hissi \\
\hline & Lab.-1 & 23 & 37 & 8 & Kuru Hava & Rahat Ortam Hissi \\
\hline & Ana Koridor & 20 & 40 & 6 & Kuru Hava & Rahat Ortam Hissi \\
\hline \multirow{4}{*}{ OKUL 4} & Giriş/ Danışma & 22 & 34 & 5 & Kuru Hava & Rahat Ortam Hissi \\
\hline & Derslik-1 & 23 & 46 & 11 & Çok Rahat Hava & Rahat Ortam Hissi \\
\hline & Derslik-2 & 24 & 49 & 12 & Rahat Hava & Rahat Ortam Hissi \\
\hline & Derslik-3 & 23 & 69 & 17 & Nemli Hava & Rahat Ortam Hissi \\
\hline
\end{tabular}




\begin{tabular}{|l|l|l|l|l|l|l|}
\hline & Lab.-1 & 22 & 52 & 12 & Rahat Hava & Rahat Ortam Hissi \\
\cline { 2 - 6 } & Ana Koridor & 20 & 66 & 13 & Rahat Hava & Rahat Ortam Hissi \\
\hline
\end{tabular}

Tablo 4'te yer alan mevcut isıl konfor şartları incelendiğinde okulların ideal sıcaklık değerleri $10-20^{\circ} \mathrm{C}$ arasında olması gerekmektedir. Bu doğrultuda sıcaklık uygunluğu bakımından en uygun ortam Okul 1'de tespit edilmiştir. Okul 2, Okul 3 ve Okul 4'te ise genel olarak giderek artış gösteren sıcaklık değerleri tespit edilmiştir. Aralık ayında yapılan ölçümler sonucunda tüm okullarda sıcaklık değerlerinin ya üst sınıra çok yakın ya da daha sıcak olduğu görülmüştür. Ayrıca araştırma kapsamında incelenen okullardaki bağıl nem değerlerinin genel olarak uygun değerlerde olması nedeni ile sıcaklık ve bağıl nem ilişkisi sonucunda biyoharmolojik açıdan rahat hava ve dolayısıyla rahat ortam hissi oluştuğu anlaşılmıştır.

Tablo 5. Mevcut Okullardaki IPI Koruma Değerlendirmesi: Doğal Yaşlanma Durumu [14 ve 17]

\begin{tabular}{|c|c|c|c|c|c|}
\hline \multirow[b]{2}{*}{ OKULLAR } & \multicolumn{5}{|c|}{$\begin{array}{l}\text { IMAGE PERMANENCE INSTITUTE (IPI) KORUMA DEĞERLENDİRMESİ } \\
\text { Çürüme Tipi: DOĞAL YAŞLANMA }\end{array}$} \\
\hline & İncelenen Ortam & $\begin{array}{l}\text { Çevre } \\
\text { Değerlendirmesi }\end{array}$ & $\begin{array}{l}\text { Koruma } \\
\text { Metriği }\end{array}$ & $\begin{array}{l}\text { Koruma } \\
\text { İndeksi } \\
\text { Sonucu }\end{array}$ & $\begin{array}{l}\text { Koruma Öğesi } \\
\text { Açısından } \\
\text { Değerlendirme }\end{array}$ \\
\hline \multirow{6}{*}{ OKUL 1} & Giriș/ Danışma & $\mathrm{OK}$ & Kİ Değeri & 58 & Uygun \\
\hline & Derslik-1 & Risk & Kİ Değeri & 33 & Uygun Değil \\
\hline & Derslik-2 & Risk & Kİ Değeri & 38 & Uygun Değil \\
\hline & Derslik-3 & Risk & Kİ Değeri & 29 & Uygun Değil \\
\hline & Lab.-1 & Risk & Kİ Değeri & 44 & Uygun Değil \\
\hline & Ana Koridor & $\mathrm{OK}$ & Kİ Değeri & 48 & Uygun \\
\hline \multirow{6}{*}{ OKUL 2} & Giriş/ Danışma & $\mathrm{OK}$ & Kİ Değeri & 54 & Uygun \\
\hline & Derslik-1 & Risk & Kİ Değeri & 27 & Uygun Değil \\
\hline & Derslik-2 & Risk & Kİ Değeri & 35 & Uygun Değil \\
\hline & Derslik-3 & Risk & Kİ Değeri & 39 & Uygun Değil \\
\hline & Lab.-1 & Risk & Kİ Değeri & 42 & Uygun Değil \\
\hline & Ana Koridor & $\mathrm{OK}$ & Kİ Değeri & 49 & Uygun \\
\hline \multirow{6}{*}{ OKUL 3} & Giriş/ Danışma & $\mathrm{OK}$ & Kİ Değeri & 51 & Uygun \\
\hline & Derslik-1 & OK & Kİ Değeri & 45 & Uygun \\
\hline & Derslik-2 & Risk & Kİ Değeri & 38 & Uygun Değil \\
\hline & Derslik-3 & Risk & Kİ Değeri & 31 & Uygun Değil \\
\hline & Lab.-1 & Risk & Kİ Değeri & 43 & Uygun Değil \\
\hline & Ana Koridor & OK & Kİ Değeri & 58 & Uygun \\
\hline \multirow{6}{*}{ OKUL 4} & Giriş/ Danışma & $\mathrm{OK}$ & Kİ Değeri & 53 & Uygun \\
\hline & Derslik-1 & Risk & Kİ Değeri & 34 & Uygun Değil \\
\hline & Derslik-2 & Risk & Kİ Değeri & 28 & Uygun Değil \\
\hline & Derslik-3 & Risk & Kİ Değeri & 19 & Uygun Değil \\
\hline & Lab.-1 & Risk & Kİ Değeri & 33 & Uygun Değil \\
\hline & Ana Koridor & Risk & Kİ Değeri & 29 & Uygun Değil \\
\hline
\end{tabular}

Okul 1, 2, 3 ve 4'te doğal yaşlanmanın aralık ayında neredeyse tüm dersliklerde risk oluşturduğu, Giriş bölümlerinde konum itibarı ile hava sirkülasyonunun yoğun olması nedeni ile doğal yaşlanma riskinin oluşmadığ 1 anlaşılmaktadır.

Tablo 6. Mevcut Okullardaki IPI Koruma Değerlendirmesi: Mekanik Hasar Durumu [14 ve 17].

\begin{tabular}{|c|c|c|c|c|c|}
\hline \multirow[b]{3}{*}{ OKULLAR } & \multicolumn{5}{|c|}{ IMAGE PERMANENCE INSTITUTE (IPI) KORUMA DEĞERLENDİRMESİ } \\
\hline & \multicolumn{5}{|c|}{ Çürüme Tipi: MEKANİK HASAR } \\
\hline & İncelenen Ortam & $\begin{array}{l}\text { Çevre } \\
\text { Değerlendirmesi }\end{array}$ & $\begin{array}{l}\text { Koruma } \\
\text { Metriği }\end{array}$ & $\begin{array}{l}\text { Koruma } \\
\text { İndeksi } \\
\text { Sonucu }\end{array}$ & $\begin{array}{l}\text { Koruma Öğesi } \\
\text { Açısından } \\
\text { Değerlendirme }\end{array}$ \\
\hline \multirow{6}{*}{ OKUL 1} & Giriş/ Danışma & OK & DNI (\%) & 7,7 & Oluşmaz \\
\hline & Derslik-1 & Ok & DNI (\%) & 12 & Oluşmaz \\
\hline & Derslik-2 & Ok & DNI (\%) & 12,2 & Oluşmaz \\
\hline & Derslik-3 & Risk & DNI $(\%)$ & 13,2 & Oluşur \\
\hline & Lab.-1 & Ok & DNI (\%) & 9,3 & Oluşmaz \\
\hline & Ana Koridor & $\mathrm{Ok}$ & DNI (\%) & 8,8 & Oluşmaz \\
\hline \multirow{6}{*}{ OKUL 2} & Giriş/ Danışma & Ok & DNI (\%) & 7,4 & Oluşmaz \\
\hline & Derslik-1 & Ok & DNI $(\%)$ & 11,8 & Oluşmaz \\
\hline & Derslik-2 & Ok & DNİ (\%) & 9,1 & Oluşmaz \\
\hline & Derslik-3 & Ok & DNI $(\%)$ & 7,8 & Oluşmaz \\
\hline & Lab.-1 & Ok & DNI (\%) & 7,4 & Oluşmaz \\
\hline & Ana Koridor & $\mathrm{Ok}$ & DNI (\%) & 7,9 & Oluşmaz \\
\hline \multirow{3}{*}{ OKUL 3} & Giriş/ Danışma & $\mathrm{Ok}$ & DNI (\%) & 6,9 & Oluşmaz \\
\hline & Derslik-1 & Ok & DNI (\%) & 9,1 & Oluşmaz \\
\hline & Derslik-2 & Ok & DNI (\%) & 9,4 & Oluşmaz \\
\hline
\end{tabular}




\begin{tabular}{|c|c|c|c|c|c|}
\hline & Derslik-3 & Ok & DNİ (\%) & 9 & Oluşmaz \\
\hline & Lab.-1 & Ok & DNİ (\%) & 7,2 & Oluşmaz \\
\hline & Ana Koridor & $\mathrm{Ok}$ & DNI (\%) & 7,7 & Oluşmaz \\
\hline \multirow{6}{*}{ OKUL 4} & Giriș/ Danışma & Ok & DNI (\%) & 6,8 & Oluşmaz \\
\hline & Derslik-1 & Ok & DNİ (\%) & 8,6 & Oluşmaz \\
\hline & Derslik-2 & Ok & DNI (\%) & 9 & Oluşmaz \\
\hline & Derslik-3 & Risk & DNI $(\%)$ & 12,8 & Oluşur \\
\hline & Lab.-1 & Ok & DNİ (\%) & 9,5 & Oluşmaz \\
\hline & Ana Koridor & Ok & DNI (\%) & 12,2 & Oluşmaz \\
\hline
\end{tabular}

Araştırma kapsamında incelenen okullarda mekanik hasar bakımından hem Okul 1 hem de Okul 4'te bulunan Derslik 3'lerin risk altında olduğu anlaşılmaktadır. $\mathrm{Bu}$ derslikler dışında tüm okulların mekanik hasar riskinin bulunmadığ 1 dikkat çekmektedir.

Tablo 7. Mevcut Okullardaki IPI Koruma Değerlendirmesi: Küf Risk Durumu [14 ve 17].

\begin{tabular}{|c|c|c|c|c|c|}
\hline \multirow[b]{3}{*}{ OKULLAR } & \multicolumn{5}{|c|}{ IMAGE PERMANENCE INSTITTUTE (IPI) KORUMA DEĞERLENDİRMESİ } \\
\hline & \multicolumn{5}{|c|}{ Çürüme Tipi: KÜF RİSKİ } \\
\hline & İncelenen Ortam & $\begin{array}{l}\text { Çevre } \\
\text { Değerlendirmesi }\end{array}$ & $\begin{array}{l}\text { Koruma } \\
\text { Metriği }\end{array}$ & $\begin{array}{l}\text { Koruma } \\
\text { İndeksi } \\
\text { Sonucu }\end{array}$ & $\begin{array}{l}\text { Koruma Öğesi } \\
\text { Açısından } \\
\text { Değerlendirme }\end{array}$ \\
\hline \multirow{6}{*}{ OKUL 1} & Giriş/ Danışma & İyi & KG & Risk Yok & Oluşmaz \\
\hline & Derslik-1 & İyi & KG & Risk Yok & Oluşmaz \\
\hline & Derslik-2 & İyi & KG & Risk Yok & Oluşmaz \\
\hline & Derslik-3 & Risk & KG & 168 & Oluşur \\
\hline & Lab.-1 & İyi & KG & Risk Yok & Oluşmaz \\
\hline & Ana Koridor & İyi & KG & Risk Yok & Oluşmaz \\
\hline \multirow{6}{*}{ OKUL 2} & Giriș/ Danışma & İyi & KG & Risk Yok & Oluşmaz \\
\hline & Derslik-1 & İyi & KG & Risk Yok & Oluşmaz \\
\hline & Derslik-2 & İyi & KG & Risk Yok & Oluşmaz \\
\hline & Derslik-3 & İyi & KG & Risk Yok & Oluşmaz \\
\hline & Lab.-1 & İyi & KG & Risk Yok & Oluşmaz \\
\hline & Ana Koridor & İyi & KG & Risk Yok & Oluşmaz \\
\hline \multirow{6}{*}{ OKUL 3} & Giriş/ Danışma & İyi & KG & Risk Yok & Oluşmaz \\
\hline & Derslik-1 & İyi & KG & Risk Yok & Oluşmaz \\
\hline & Derslik-2 & İyi & KG & Risk Yok & Oluşmaz \\
\hline & Derslik-3 & İyi & KG & Risk Yok & Oluşmaz \\
\hline & Lab.-1 & İyi & KG & Risk Yok & Oluşmaz \\
\hline & Ana Koridor & İyi & KG & Risk Yok & Oluşmaz \\
\hline \multirow{6}{*}{ OKUL 4} & Giriş/ Danışma & İyi & KG & Risk Yok & Oluşmaz \\
\hline & Derslik-1 & İyi & KG & Risk Yok & Oluşmaz \\
\hline & Derslik-2 & İyi & KG & Risk Yok & Oluşmaz \\
\hline & Derslik-3 & Risk & KG & 227 & Oluşur \\
\hline & Lab.-1 & İyi & KG & Risk Yok & Oluşmaz \\
\hline & Ana Koridor & İyi & KG & Risk Yok & Oluşmaz \\
\hline
\end{tabular}

İncelenen okullarda küf riskinin, mekanik hasar değerlendirmesinde de olduğu gibi genel olarak tüm okullarda her hangi bir tehdidin söz konusu olmadığ anlaşılmaktadır.

Tablo 8. Mevcut Okullardaki IPI Koruma Değerlendirmesi: Metal Korozyon Durumu [14 ve 17].

\begin{tabular}{|c|l|l|l|l|l|}
\multicolumn{5}{c|}{ IMAGE PERMANENCE INSTITUTE (IPI) KORUMA DEĞERLENDİRMESİ } \\
\cline { 2 - 7 }
\end{tabular}




\begin{tabular}{|c|c|c|c|c|c|}
\hline & Ana Koridor & Ok & DNİ (\%) & 7,9 & Oluşmaz \\
\hline \multirow{6}{*}{ OKUL 3} & Giriș/ Danıșma & İyi & DNI (\%) & 6,9 & Oluşmaz \\
\hline & Derslik-1 & $\mathrm{Ok}$ & DNI (\%) & 9,1 & Oluşmaz \\
\hline & Derslik-2 & $\mathrm{Ok}$ & DNI (\%) & 9,4 & Oluşmaz \\
\hline & Derslik-3 & Ok & DNI $(\%)$ & 9 & Oluşmaz \\
\hline & Lab.-1 & $\mathrm{Ok}$ & DNI $(\%)$ & 7,2 & Oluşmaz \\
\hline & Ana Koridor & Ok & DNI $(\%)$ & 7,7 & Oluşmaz \\
\hline \multirow{6}{*}{ OKUL 4} & Giriş/ Danışma & İyi & DNI $(\%)$ & 6,8 & Oluşmaz \\
\hline & Derslik-1 & $\mathrm{Ok}$ & DNI (\%) & 8,6 & Oluşmaz \\
\hline & Derslik-2 & Ok & DNI (\%) & 9 & Oluşmaz \\
\hline & Derslik-3 & Risk & DNI (\%) & 12,8 & Oluşur \\
\hline & Lab.-1 & Ok & DNI $(\%)$ & 9,5 & Oluşmaz \\
\hline & Ana Koridor & Risk & DNİ (\%) & 12,2 & Oluşur \\
\hline
\end{tabular}

Aralık ayında Okul 1'de tüm dersliklerde, Okul 2 ve Okul 4'te bazı dersliklerde ve Okul 4'de ana koridorda metal korozyonunun oluşacağı belirlenmiștir.

\section{SONUCC VE ÖNERILER}

Eğitim ortamlarındaki nem oranı, \%30-70 RH arasinda gözlenmesi beklenen bir huzur kriteridir. Nem oranı \%30'un altına düştüğünde yaşam için "kuru ve uygun olmayan ortamlar" söz konusu olmaktadır. Buna bağlı olarak oluşan toz, baş ağrısı, göz enfeksiyonları, yorgunluk ve solunumda kuruluk gibi çeşitli hastalıklar meydana gelebilmektedir. $\mathrm{Bu}$ oranın \%70'in üzerine çıktığı durumlarda ise "küf ve bakteriler etkin" hale gelerek yapı ve insan sağlığınıtehdit edecekzararlı etkiler belirmektedir.

Yüksek nem sonucunda, hem yap1 kabuğunda küflenme hem de malzeme yapısında bozulmalar gözlenir. $\mathrm{Bu}$ durum, yapıların kullanım değerini (ömrünü) düşürür. Ayrıca bu duruma ek olarak, iç ortam havasının insan sağlığı üzerindeki etkileriolarak solunum yolu rahatsızlıkları, romatizmal rahatsızlıklar, astım, alerjive akciğer hastalıkları gibi birçok problem karşımıza çıkmaktadır. Bu konuda yapılanbazı araştırmalara göre, kronik olarak görülen bu tür hastalıkların, havayla taşınan mikroorganizmalarla iliş̧kili oldukları belirtilmiştir. Havayla taşınan mikroorganizmalar \%80-90 RH gibi yüksek nem değerlerine maruz kaldıklarında, daha aktif olurlar ve insanlar için yüksek tehlike yaratabilirler. Yapılan deneysel çalışma kapsamında yer alan Elazı̆̆ ve Malatya illeri karasal iklim (yazlar sıcak ve kurak, kışlar soğuk ve yağışı) bölgesinde yer aldıkları için yıllık ortalama nem oranı $\% 60$ civarındadır. Bu nedenle iç ortam nem miktarının yüksek (\%60-70 üzeri) olması beklenmez. Ayrıca, nem oranının \%30 altında olması (kuru hava), şartların iyileştirilmediği durumlarda gözlemlenebilir [14 ve 18$]$.

Okullarda ve diğer yapılarda en önemli hava kalitesi parametrelerinden biride sıcaklıktır. Eğer belirli bir eğitim ortamında, öğrenci/kullanıcı, kendisini rahat hissediyorsa; ortamın daha sıcak veya daha soğuk olmasını istemiyorsa, sıcaklık derecesinin uygun olduğu kanısına varılır. Fakat sıcaklık ve buna bağlı olarak nem değerleri arttıkça kullanıcılar aşırı derecede rahatsızlık duyar, başarı ve görev performansları bozulur, öğrenme ve ögretme yeterlilikleri ile birlikte moralleri de olumsuz yönde etkilenir [14].

Sınıfın aşırı derecede sıcak veya soğuk olması, öğrencilerin derslere karşı olankonsantrasyonunu olumsuz yönde etkiler. Sınıf sıcaklığının düzenlenmesi, 1sitıcı veya soğutucularla yapılabileceği gibi, öğrencilere sıcaklık değişimleri doğrultusunda 1S1 ile tutarlı giysi önerilmesiyle de yapılabilir. Çünkü sınıf sıcaklığı; mevsimlere ve neme olduğu kadar öğrencilere göre de değişmektedir. Giyim ve sınıfın fiziksel koşulları, sıcaklığın etki derecesini değiştirir. Sıcaklık derecesinin yükselmesi fiziksel rahatsızlıklara, zihninin gevşemesine, ilginin dağılmasına ve bunların neden olabileceği sorunlara yol açmaktadır. Düşük sıcaklık ise öğrencinin çabalarını 1sınmaya yöneltmekte, zihnini öğretime odaklamasını güçleştirmektedir. Bu doğrultuda eğitim yapılarında; tüm alanlar kullanım saatleri boyunca $10-20^{\circ} \mathrm{C}$ arasında olacak şekilde 1sitllip/soğutularak dengede tutulmalıdır [14].

Çalışma kapsamında yer alan okullarda yapılan ölçümlerden anlaşılacağı gibi sıcaklık ölçümlerinde Aralık ayı için sınır değerler ile birlikte yükssek değerler tespit edilmiştir. Bağıl nem değerlerinin ise standart değerlerde olduğu tespit edilmesine rağmen sıcaklık ve bağıl nem değerlerine göre oluşan çiğ noktası sıcaklık değerleri sonucunda (Tablo 1' d verilen BUD değerlendirmesi doğrultusunda) ortamda kuru ve nemli havanın mevcut olması kullanıcılar açısından uygun olmayan ve çok elverişsiz ortamlardır [14 ve 15].

Okul, bütün topluluklarda önemli bir kuruluştur. Eğitimin kalitesini yükseltmek için kamusal girişimler, farklı yaklaşımların başlıca esasları üzerine olmasından dolayı, bütün okullar için bazı gerçekleri geçerli kılmaktadır. $\mathrm{Bu}$ gerçeklerden biri; okulların içinde bulunduğu durum; personelin ve öğrencilerin sağlığını, performanslarını ve ruhsal durumunu önemli derecede etkileyebilmesidir [10]. Öğrenciler ve okul personeli uygun olmayan değerlerdeki iç ortam hava kalitesinin olumsuz etkilerinden zarar görebilirler. Fiziki ortamdaki biyolojik maddeler ve kimyasal toksinler sağlikla ilgili tehlikelerin ve olumsuz eğitim ortamlarının ortaya 
çıkmasına yol açabilir. Bu durumun birçok farklı vücut sistemlerini etkilemesinin yanı sıra sağlı, öğrenme derecesi ve verimliliği de etkilemektedir. Bu etkiler hem geçici ya da uzun süreli olabilir hem de hafif rahatsızlıklar oluşturan belirtilerden ciddi ve sürekli rahatsızlıkların meydana çıkmasına kadar uzanabilmektedir [3].

Kapalı ortamların hava kalitesi, kullanılan eşyalardan, inşa malzemelerinden, kişilerin aktivitelerinden ve dışarıdan yapı içerisine giren kirletici maddelerden (katı ve gaz gibi) kaynaklanmaktadır. Son zamanlarda bina yapım teknolojisinde enerjinin korunmasi ve 1s1 yalitımının yapılabilmesi amaciyla oluşan gelişmeler yapının içi ile dışı arasında hava dolaşımını engellediğinden yapının iç ortamlarında zamanla artış gösteren bir hava kirliliği problemi doğurmuştur. İç ortamdaki kirleticilere maruz kalmak, diş ortamdaki kirleticilere maruz kalmakla karşılaştırıldığında sağlık bakımından daha fazla risk taşımaktadır. Çünkü kişiler yaşamlarının büyük bir bölümünü iç ortamda geçirmekte ve bazı kirleticilerin bina içi atmosferindeki miktarları genellikle dış ortamdaki düzeyleri geçmektedir. Amerikan Çevre Koruma Ajansı (EPA) aracılığıyla yürütülen çalışmalar kişilerin kapalı alanlarda açık alanlara göre 2 ya da 5 kat daha fazla zararlı bileşiklere maruz kaldığını ortaya çıkarmıştır [3].

Çiğ noktası sıcaklığı; hem insanlar hem de yapılar üzerine bazı etkilerde bulunmaktadırlar. BUD değerleri doğrultusunda insanlar açısından oluşabilecek etkileri belirlenirken, eğitim yapılarını oluşturan malzemeler üzerindeki etkileri IPI koruma değerlendirmesi yöntemi ile belirlenmektedir. Çiğ noktası sıcaklığı fiziki ortamda kimyasal bir reaksiyon oluşturmaktadır. Oluşan reaksiyonun hızını artırmak 1sı enerjisi ortaya çıkarır ve bu 1sı enerjisi ile birlikte bağıl nem de kimyasal çürüme hızını etkiler. Bu doğrultuda malzemeler sıcak ve nemli ortamlarda hızlı, serin ve kuru ortamlarda ise yavaş bozunur. Dolayısı ilekağıt, ahşap, plastik ve boya gibi organik maddeler açısından doğal yaşlanma riskinin oldukça önemli olduğu anlaşılmaktadır. Ayrıca bu tür kimyasal bozunmalar malzemelerin kırılganlığını arttır ve pigmentleri bozunur [17].

Sıcaklık değerlerinin çok düşük olmasıveya yüksek bağıl nem değerlerinintespit edildiği çevrelerde mekanik hasarlar oluşmaktadır. Bu hasarlar malzemeler üzerinde (özelliklede kompozit malzemeler üzerinde) diferansiyel genişleme, kırılma, yırtılma ve çatlamalara yol açmaktadır. Bağıl nem değerlerinin eğitim yapılarında \%30-70 arasında olması gerekmektedir. Isı ve yüksek değerlerdeki nemli ortamlarda küf sporları daha çok yayılmaktadır. \%70'in altında tespit edilen bağıl nem değerleri büyük ölçüde küf ve biyolojik çürüme risklerini azaltmaktadır [17]. Küflerin kendileri kadar oluşturdukları toksinler de kişilerin sağlığı açısından oldukça tehlikelidir [2].
Çok yüksek nem ya da yüksek sıcaklık değerlerinin varlığ1 ortamda atmosferik kirleticilerin ve korozyonunvar olmasına neden olmaktadır. \%58' in üzerinde tespit edilen bağıl nem değerleri korozyonun başlaması için gerekli ortamı oluşturabilmektedir. Kirlilik, toz ya da aktif korozyonun oluşması düşük nem seviyelerinde de korozyonun oluşmasına neden olabilir [17].

Tespit edilen sıcaklık değerlerinin Biyoharmolojik uygunluk değerlendirmesine göre araştırma kapsamındaki tüm okullarda "rahat ortam hissi" oluşturduğu ancak sicaklık-bağıl nem değerleri ile hesaplanan çiğ noktası sıcaklık değerleri bakımından bütün okullarda uygun olmayan kuru hava ya da nemli hava ortamlarının oluştuğu anlaşılmaktadır.

Ayrıca kapalı ortamlardaki hasar tipleri ortamda biyolojik kirleticilerin (mantar sporları, virüsler, böcekler, bakteriler, akarlar vs.) varlığına sebep olabilmektedir. Bu tür biyolojik kirleticiler ise toksik ve alerjik etkiler yapabilirler. Aşırı kalabalık ortamlar ve kötü yaşam koşullarına bağlı olarak aynı ortamı paylaşan kişilerde hastalıkların yayılımı daha da kolay olmaktadır. $\mathrm{Bu}$ nedenle eğitim yapılarında nem kontrolü, havalandırma ve temizlik bu kirleticilerin oranlarını büyük ölçüde düşürmektedir [2].

Sonuç olarak, araştırma kapsamında yer alan bütün okullarda IPI koruma değerlendirmesi doğrultusunda doğal yaşlanma riskinin oluştuğu sıcaklık ve bağıl nem değerleri ölçülmüştür. IPI koruma değerlendirmesine göre mekanik hasar, küf riski ve metal korozyonu risklerinin sadece Okul 3'te hiç oluşmadığı anlaşılmıştır. $\mathrm{Bu}$ üç risk durumu göz önüne alındığında en iyi den en kötüye doğru bir siralama yapacak olursak Okul 3'ten sonra iyi durumda olan okullar sirasıyla Okul 2, Okul 4 ve Okul 1 gelmektedir. Binalarda isı yalıtımının sağlanamaması ve mekanik 1sıtma, soğutma ve havalandırma sistemlerin bulunmaması gibi nedenlerden dolayı BUD ve IPI koruma değerlendirmelerine esas olan standart dışı sıcaklık ve bağıl nem değerlerinin tespit edildiği söylenebilir.

\section{KAYNAKLAR}

[1]. Karaçalı, A. (2006). Sınıf Yönetimini Etkileyen Fiziksel Değişkenlerin Değerlendirilmesi, Gazi Üniversitesi Kırşehir Eğitim Fakültesi, Cilt:7, Say1:1, s:145-155.

[2]. Ekinci, C.E. (2007). Biyoharmoloji, Data Yayın Evi, Elazı ̆

[3]. Öztürk, B. ve Düzovalı, G. (2011). Okullarda Hava Kirliliği ve Sağlık Etkileri, X. Ulusal Tesisat Mühendisliği Kongresi, İç Hava Kalitesi Sempozyumu, s:1715-1723, İzmir. 
[4]. Akgül, M. (2010). Yapılarda Huzur Kriterlerinin İncelemesi, Yüksek Lisans Tezi, F.Ü. Fen Bilimleri Enstitüsü, Elazığ.

[5]. Mendall, M.J. \&Heath, G.A. (2005). Do Indoor Pollutantsand Thermal Conditions in Schools İnfluence Student Performance? A Critical Review of The Literature, Indoor Air Journal, Vol:15, pp:27-32.

[6]. Ming-Tak, H. \& Wai-Shing, L. (2008). Classroom Management: Creating a Positive Learning Environment, Hong Kong University Press, Hong Kong.

[7]. Anstrand, D. \& Kirkbride, E.E. (2006). TheEducation Environment Program, Design Share

(http://www.designshare.com/index.php/articles/e ducation-environment-program/2/), Erişim Tarihi: 21.04.2016.

[8]. Sanoff, H. (2011). School Building Assessment Methods, National Clearinghouse for Educational Facilities (ERİC No: ED448588), Washington.

[9]. Gedik, G.Z., Ünver, R. ve Yüksel, Z.K., 2004. Bir Kütüphane Yapısının Sessel, Görsel ve Isısal Konfor Koşulları Açısından İncelenmesi, Sürdürülebilir Çevre İçin Enerji Denetimi-Yalıtım Kongresi ve Sergisi Bildiriler Kitab1, s:73-79, İstanbul.

[10]. Demir, C. (2011). Eğitim Kurumlarında Mekan Yönetimi, Yüksek Lisans Tezi, F. Ü. Sosyal Bilimler Enstitüsü, Elazı̆̆.

[11]. Hutchison, D.C. (2004). A Natural History of Place in Education, Teachers Collage Press, New York.
[12]. Kunszt, G. (2003). Sustainable Architecture, Periodica Polytechnica, Civil Engineering, Vol:47, No:1, pp:5-10.

[13]. Kılıç, N.D. ve Gedik, G.Z.,(2004). Okul Yapılarının Plan Tiplerinin Yıllık Isıtma Enerjisi Tüketimi Açısından Karşılaştırılması, Sürdürülebilir Çevre İçin Enerji Denetimi-Yalıtım Kongresi ve Sergisi Bildiriler Kitab1, s:89-95, İstanbul.

[14]. Ay, S.(2013). İlköğretim Birinci Kademe Eğitim Yapılarının Biyoharmolojik Uygunluk Değerlerinin Deneysel Olarak Değerlendirilmesi Elazığ İli Örneği, Yüksek Lisans Tezi, F.Ü. Fen Bilimleri Enstitüsü, Elazığ.

[15]. Ay, S. ve Ekinci, C. E. (2016). Evaluation of ThermalComfortConditionsInTerms of Educational Environment andUsers, International Conference on Natural ScienceandEngineering (ICNASE'16), Tam Metin Tebliğler, pp:552-564, Kilis.

[16]. Ekinci, C.E.(2013). Elazı̆̆ Yatılı Bölge Ortaokulların Biyoharmolojik Özelliklerinin İncelenmesi, Yayınlanmamış Doktora Tezi, Elazı̆̆: Fırat Üniversitesi Eğitim Bilimleri Enstitüsü, Elazı̆̆.

[17]. Web-1: http://www.dpcalc.org/, Erişim Tarihi: 04.01.2016.

[18]. Baykuş, N.(2012). Hastane Yapılarının Biyoharmolojik Uygunluk Değerlerinin Deneysel Olarak İncelenmesi, Yüksek Lisans Tezi, F.Ü. Fen Bilimleri Enstitüsü, Elazığ. 